\title{
History of the llizarovs wire-fixator, stages of hand surgery development at the llizarov Center
}

\author{
V.I. Shevtsov ${ }^{1}$, A.P. Kirienko ${ }^{2}$, N.G. Shikhaleva ${ }^{1}$, K.I. Novikov ${ }^{1}$ \\ ${ }^{1}$ Ilizarov National Medical Research Centre for Traumatology and Orthopedics, Kurgan, Russian Federation \\ ${ }^{2}$ Humanitas Clinical and Research Center, Milan, Italy
}

\begin{abstract}
Introduction Hand surgery has its own history in each country which is done by outstanding doctors and scientists. Academician G.A. Ilizarov, the founder of transosseous osteosynthesis, is one of such personalities. Purpose of the work To analyze the stages of development and application of transosseous osteosynthesis in hand surgery, proposed by Academician G.A. Ilizarov. Methods The process of creation and development of transosseous osteosynthesis for short tubular bones was analyzed. We present the main designs and developers of the inventions related to extrafocal osteosynthesis of hand bones. The structural divisions of the Ilizarov Center, in which medical care was provided to the patients with hand pathology, were stated. Results The entire existence and active use of the Ilizarov mini-fixator can be represented by five periods, starting from the period of comprehending the need for its design. Currently, we are in the period of its combined use in conjunction with the reconstruction of hand soft tissues. Conclusion The names of scientists who have made a significant contribution to the development of the Ilizarov method of transosseous osteosynthesis for the hand surgery were given in the final summary. Thanks to the results of their work, we have the opportunity to further develop hand surgery in accordance with the contemporary scientific requirements.
\end{abstract}

Keywords: hand surgery, Ilizarov apparatus, mini fixator, external fixation apparatus for the hand

\section{INTRODUCTION}

Hand surgery as a specialty grew out of the experience of treating upper limb injuries during World War II. Sterling Bunnell (1882-1957), doctor of medicine, was a key figure in the creation of the hand surgery specialty in the United States of America. In 1944, he published a book "Surgery of the Hand" that was an authoritative publication for almost 30 years. Around the same time, he organized and managed nine hand surgery centers. The surgeons who ran those centers became the founders of the American Society for Surgery of the Hand [1]. Based on the experience of American colleagues, the International Federation of Societies for Surgery of the Hand (IFSSH) was established in Europe in 1966. This organization was renamed into the Federation of European Societies for Surgery of the Hand (FESSH).

The Russian history of surgery also has many vivid examples of in-depth study of hand pathology. And here we need to start with the activities of the outstanding physician N.I. Pirogov (1810-1881), who laid down the basic principles of traumatology, orthopedics and surgery [2]. His initiatives were picked up by his disciples. Yu.K. Shimanovsky (1829-1868), in addition to various interventions on integumentary tissues, proposed a method of stretching the skin on amputation stumps [3].

The $20^{\text {th }}$ century was the next stage in hand surgery. Well-known scientists and surgeons made significant contributions to the development of our specialty at that time: V.I. Rozov (1887-1960), A.A. Limberg (1894-1974), V.N. Blokhin (1897-1957), B.V. Parin (1904-1968), V.K. Krasovitov (1904-1993), V.V. Azolov (1937-2013), A.M. Volkov (19082004) and many others. The name of G.A. Ilizarov belongs to this list and his scientific and practical contributions have been widely used in hand surgery nowadays [4-6].

Purpose To analyze the stages of development and application of transosseous osteosynthesis for short bones proposed by academician G.A. Ilizarov.

\section{MATERIAL AND METHODS}

The history of any scientific direction is closely and inextricably linked to the people who plan, build and implement this direction in life. The history of the development of the "hand" part of the method of transosseous osteosynthesis at the Ilizarov Center was no exception. We should start from the very beginning.

The appearance of the Ilizarov apparatus in the 1950s was a revolutionary breakthrough in traumatology and orthopedics not only in our

[d] Shevtsov V.I., Kirienko A.P., Shikhaleva N.G., Novikov K.I. History of the Ilizarovs wire-fixator, stages of hand surgery development at the Ilizarov Center. Genij Ortopedii, 2021, vol. 27, no 3, pp. 299-306. DOI 10.18019/1028-4427-2021-27-3-299-306 
country, but throughout the world. The main attention of scientists at that time was concentrated on the development of reconstructive and restorative operations on large segments of the human musculoskeletal system. In 1966 G.A. Ilizarov, after creating an external apparatus of his own design, was appointed head of the problem laboratory at the Sverdlovsk Scientific Research Institute for Traumatology and Orthopedics. At that time, the Ilizarov method of transosseous osteosynthesis began its development and subsequent practical application.

The decision to use transosseous osteosynthesis in hand surgery was not accidental. On the one hand, G.A. Ilizarov discussed the possibility of using the developed method in related specialties such as angiology, oncology, neurosurgery, dentistry and other disciplines. On the other hand, his fame served as the starting point that attracted patients with hand pathology to refer to the Ilizarov clinic. One of the first patients who underwent treatment with a miniapparatus was the director of a plant from the city of Kurgan with a fracture of the 5th metatarsal bone. Being admitted to the institute for medical care, he was offered plaster immobilization, which he rejected due to a large amount of bandages, inability to use shoes, and the need to move with crutches. So, a customized and a very miniature assembly of the apparatus for fixing a broken bone was developed. And all the disadvantages of a plaster splint were avoided.

The final decision to speed up the development of a mini-fixator was made after one of the Institute's employees applied to G.A. Ilizarov to treat her 6-yearold daughter who had brachisyndactyly of the fingers of both hands. Not only orthopedic traumatologists, but also specialists from the engineering laboratory were invited to the surgical council that discussed the upcoming reconstructive intervention on the hand. According to the terms of a technical solution, the engineers had to develop the main parts of a mini-fixator from which it was possible to assemble the units for the longitudinal and transverse traction. Thus, the referral of patients with injuries, bone defects, congenital anomalies in the hand made the team of doctors headed by G.A. Ilizarov to develop and introduce into practice a design of the fixator for interventions on small tubular bones.

In the following years, the mini-fixator passed through several stages of improvement. The main requirements for the design of the transosseous osteosynthesis apparatus for the hand were its easy assembly in the operating room, financial costeffectiveness, possibility of multiple use, ability to correct all types of displacement of bone fragments, stability of controlled fixation (compression or distraction), individual application depending on the location of a fracture, preservation of active movements in the adjacent intact joints, minimal damage to the soft tissues of the hand while maintaining blood supply to the fractured bones [7-11].

The first wire-based fixator for the hand (hand mini-fixator) was proposed by a group of authors (G.A. Ilizarov, I.A. Kataev, A.P. Predein) and registered on November 12, 1980 under No. 923535 [12]. It was a bulky structure of a complicated technical design (Fig. 1).

The following year, the authors proposed a new modification of the apparatus for small tubular bones (patent No. 973115 dated 05/18/81) [13]. The device was intended for fixation and work out of finger joints (Fig. 2).
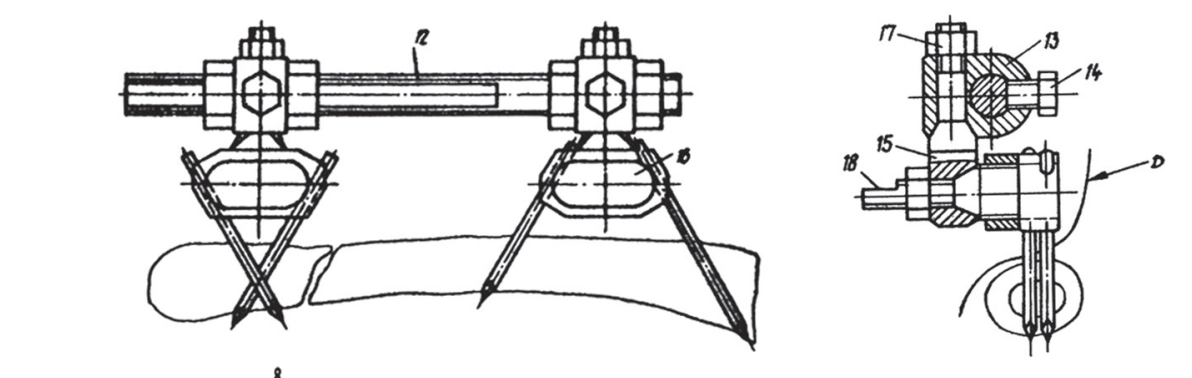

Fig. 1 Diagram of wire-based fixator, patent \# 923535 from 12.11.80
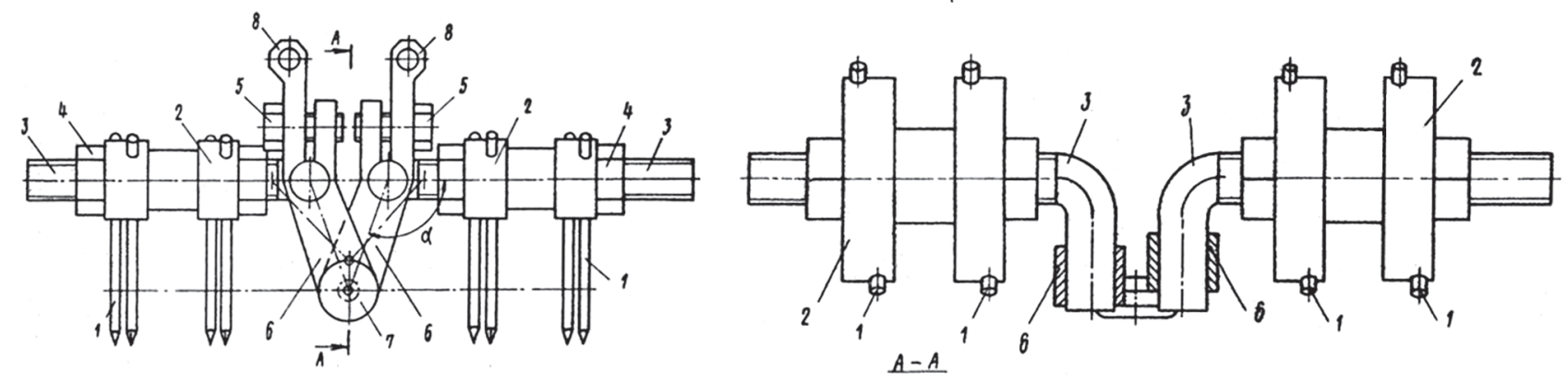

Fig. 2 Diagram of a device for fixation and training of finger joints, patent No. 973115 dated 05/18/81 
Those two designs did not find a wide application in practical work but were the foundation for a current design of the Ilizarov mini-fixator.

In 1983, a group of doctors and researchers started to treat patients with congenital developmental anomalies, correct post-traumatic and neurogenic deformities of the hand and foot. It was based at the second orthopedic department of KNIIEKOT for adults (head of the department, Murashko Vasiliy Ivanovich).

In August 1983, nurses and junior medical personnel from this department were sent to equip a new department, which was decided to deploy on the second floor of block "B" of the new building of the Center. Among them were Klepinina L.Ya., Katkova R.P., Rechkina N.P., Kataytseva L.P., and others. On December 9, 1983, the department opened its doors to patients. The first head of the new department was Okulov Gennady Vladimirovich.

The work of the department was aimed at the clinical implementation of new methods for treating patients with diseases of the hand and foot. Already in 1984, the staff of the department developed and used in practice five new methods which were used to treat 136 patients. The proposals of the staff were ten improvements of the inventions (department's 1984 annual report). The first medical team of the department for hand and foot pathology was:

- Shatokhin V.D. - orthopedic resident, graduated from the medical faculty of the Orenburg Medical Institute in 1972;

- Skolkov V.N. - orthopedic resident, graduated from the medical faculty of the 2nd Moscow Medical Institute in 1983;

- Noskova (Ignatieva) S.M. - resident physician, graduated from the medical faculty of the Novosibirsk Medical Institute in 1984;

- Kirienko A.P. - junior researcher, resident physician, graduated from the medical faculty of the Blagoveshchensk Medical Institute in 1982 (Fig. 3).

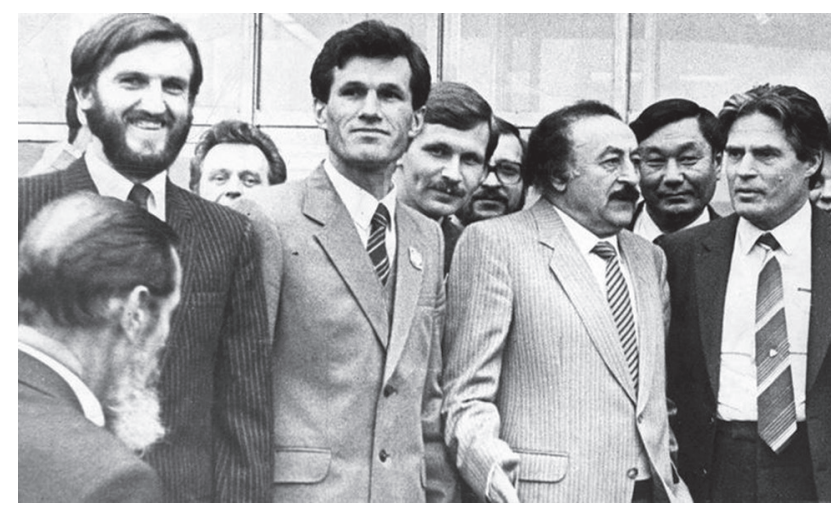

Fig. 3 From left to right: A.P. Kirienko, V.I. Kusturov, G.A. Ilizarov, A.D. Lee, Yu.G. Shaposhnikov (photo from A.P. Kirienko's archive, 1983)
In 1983 G.A. Ilizarov proposed a compressiondistraction apparatus for treatment of patients with hand pathology (Inventor's Certificate 1715333 USSR) [14]. Its design, in comparison with the previous ones, was convenient to use, versatile, i.e. it could be used for various orthopedic and traumatic pathologies of the hand (Fig. 4).

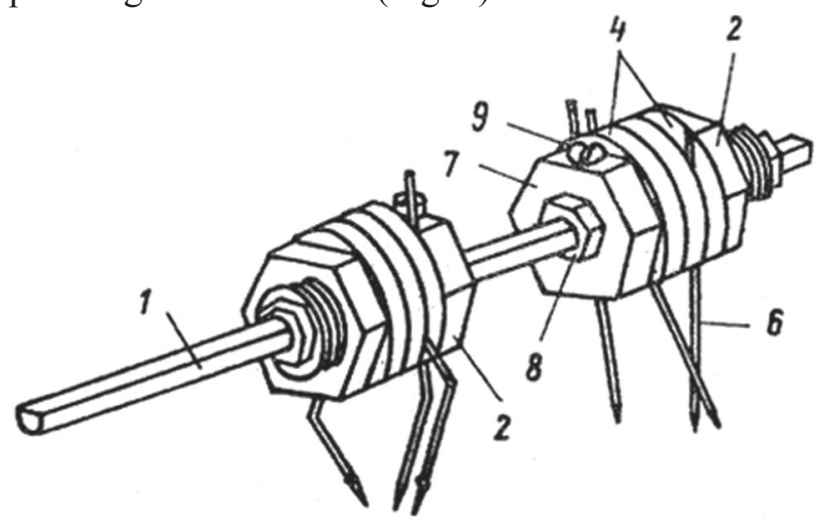

Fig. 4 Diagram of a compression-distraction apparatus for treatment of patients with hand pathology (Inventor's Certificate 1715333 USSR)

Transosseous osteosynthesis was used to increase the longitudinal dimensions of the hand segments, which was observed in patients with post-traumatic finger stumps, ectrodactyly, and brachydactyly. At that time, lengthening was performed when a stump length was at least $3 \mathrm{~cm}$. The assembly of the mini-apparatus depended on the number and size of finger stumps. If the patient had several finger stumps at the level of the proximal phalanges, the main support was installed on the metacarpal bones. One wire was inserted into the base of the stumps of the proximal phalanges, which was fixed in the distal support ring [15]. The construct was easy to assemble, but, unfortunately, the rate of distraction was the same for all elongated bones (Fig. 5).

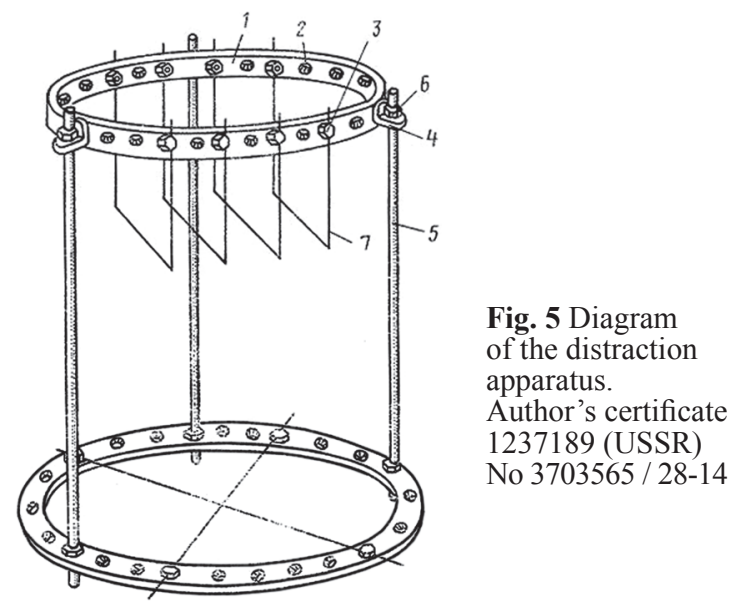

In 1984, G.A. Ilizarov proposed an apparatus for treating hypoplasia of the bones of the hand, congenital absence offingers (AC 1708320USSR) [16]. The design was intended to lengthen the metacarpal bones (Fig. 6). The wires, twisted corkscrew-like, were inserted in an 
obliquely frontal plane with their fixation on traction rods. Bayonet-like curved wires were introduced into the surgical practice, and it became possible to work separately with each bone segment. In this version of the apparatus, there were no hinged connections between the supports. One or two corkscrew-like wires passed through the distal sections of the stumps, which were attached to a common bar. The base and bar were connected together using distraction rods and hnged units. This design made it possible to change the lengthening rate separately on each bone, but, unfortunately, there was no possibility of correcting the direction of distraction.

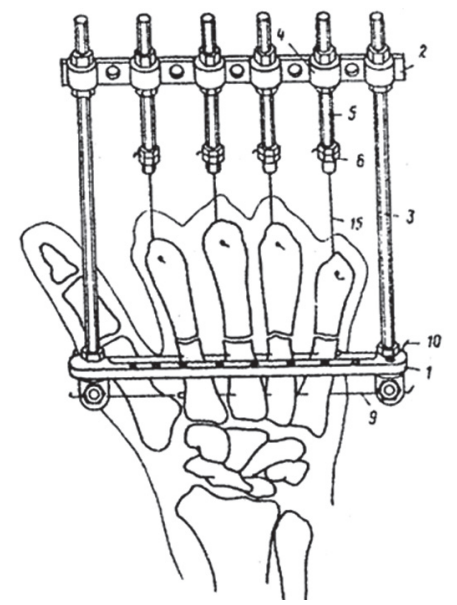

Fig. 6 Diagram of the apparatus for management of hypoplasia of the hand bones (Certificate of Authorship 1708320, USSR)

That apparatus was used not only to lengthen the metacarpal bones but also to increase the longitudinal dimensions of congenital or acquired finger stumps. By technical execution, difficulties arose not with the insertion of the corkscrew-like twisted wires but with their removal (Fig. 7). Nevertheless, this method of lengthening was practiced at the Center before the appearance of more advanced designs.

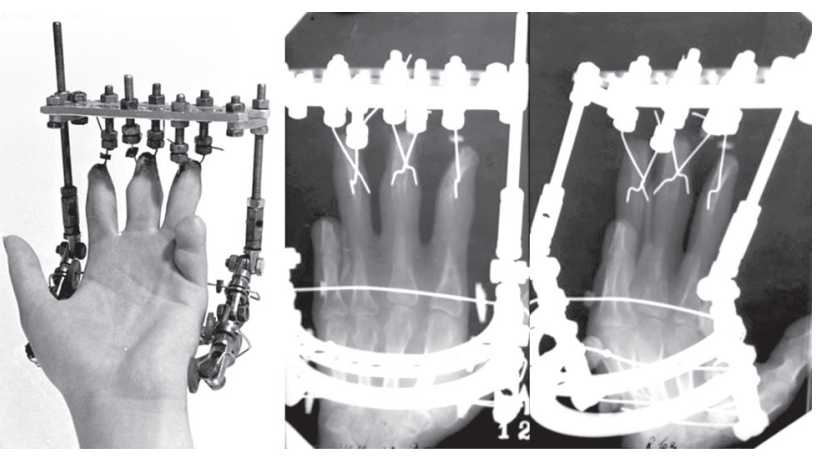

Fig. 7 Photo and radiograph of the left hand with the Ilizarov apparatus on for lengthening the stumps of the proximal phalanges of fingers 2 through 4

In 1986, G.A. Ilizarov proposed a method for managing flexion contractures of the hand [17], which the author used to eliminate the forced position of the fingers of the hand in spastic paralysis. A base support of two rings was mounted on the forearm. The wires passed through the metacarpal bones, which were attached to a half-ring. In the distal and middle phalanges of the fingers, U-shaped wires were inserted. Those wires were attached to a halfring mounted on the hand in maximum extension of the fingers. In the postoperative period, gradual extension of the hand was implemented.

The mini-fixator was gradually introduced into practice. The next step was its use for shortened tubular bones of the hand. In 1987, G.A. Ilizarov proposed a compression-distraction apparatus (mini-apparatus for separate lengthening of the bones of the hand) registered under the invention number 1708319 (Fig. 8). Its constructive feature was provision of separate lengthening of the phalanges of the fingers [18].

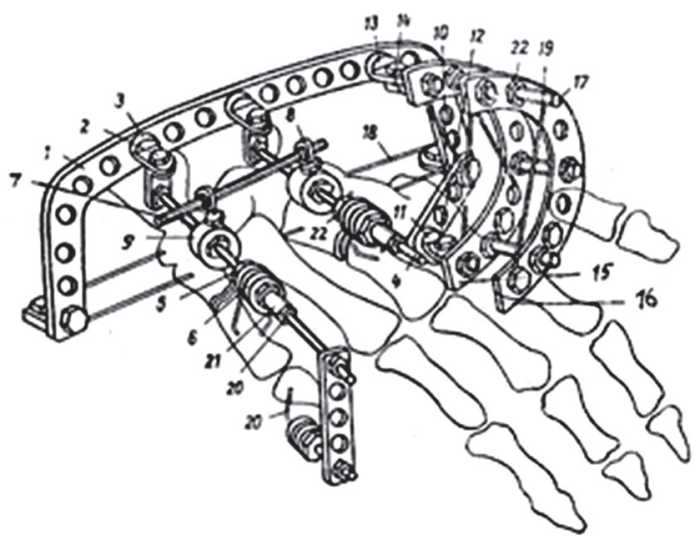

Fig. 8 Diagram of a compression-distraction apparatus (mini-apparatus for separate lengthening of hand bones), invention No. 1708319, application registered on 13.04.87

In some cases, it became necessary not only to lengthen the bones of the hand, but also to form an interdigital space. For this purpose, a technical solution was proposed by G.A Ilizarov, which provided lengthening of the first and second metacarpal bones with mini-fixators and simultaneous creation of a softtissue stock in the first intercarpal space (Fig. 9) [19].

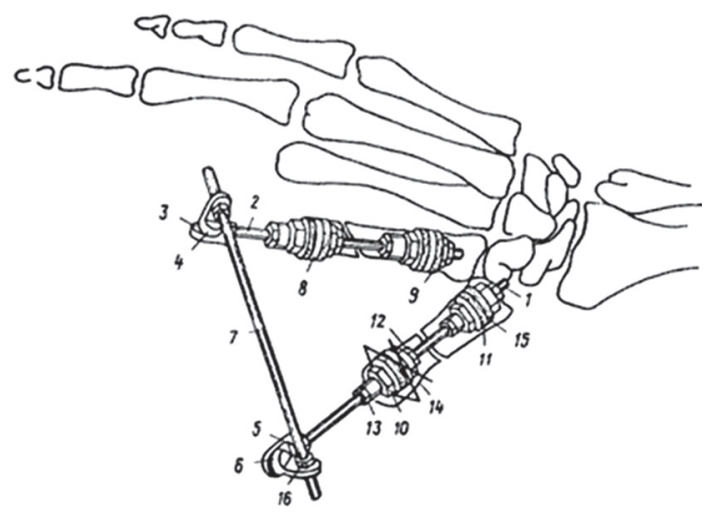

Fig. 9 Diagram of the compression-distraction apparatus (Author's Certificate 1708322 (USSR), date of registration of the application 13.04.87)

The results of the successful use of mini-fixators for correction of hand skeletal disorders awoke the interest of foreign specialists, therefore a European patent was obtained for it. Distraction apparatus for 
osteosynthesis of short tubular bones SU 8800152 W dated 1988-07-26 (Fig.10) [20].

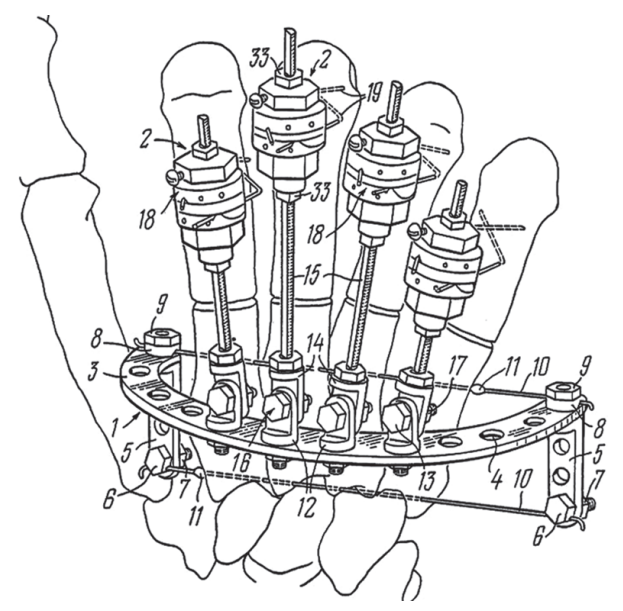

Fig. 10 Diagram of a distraction apparatus for osteosynthesis of short bones

The technical thinking continued. G.A. Ilizarov posed the task of lengthening the stumps of metacarpal bones and creating a functional bend at the level of the metacarpophalangeal joints. To solve it, he proposed osteotomies of the metacarpal bones at the level of the diaphysis. Then, in the process of lengthening, bend at the level of the regenerate to increase the area of the hand and improve the grip function. This solution was patented under the name "Distraction apparatus for plastic reconstruction of hand" SU8800140W- from 1988-07-25 (Fig. 11) [21].

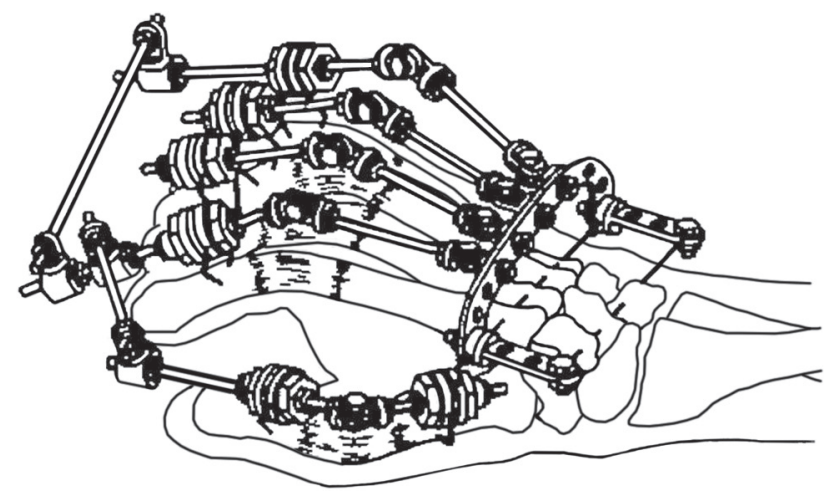

Fig. 11 Diagram of the distraction apparatus for plastic reconstruction of the hand

Foreign specialists were very interested in hand reconstruction with the use of transosseous osteosynthesis and the mini-apparatus. Regular scientific meetings with foreign colleagues were held (Fig. 12).

In addition to increasing the longitudinal dimensions of the bones of the hand, G.A. Ilizarov set the task of increasing their transverse dimensions. For this purpose, he proposed a "Method for the treatment of hand hypoplasia" [22]. It described in detail the techniques for splitting the metacarpal bones, insertion of olive wires with fixation and further transport of bone fragments in the transverse direction.

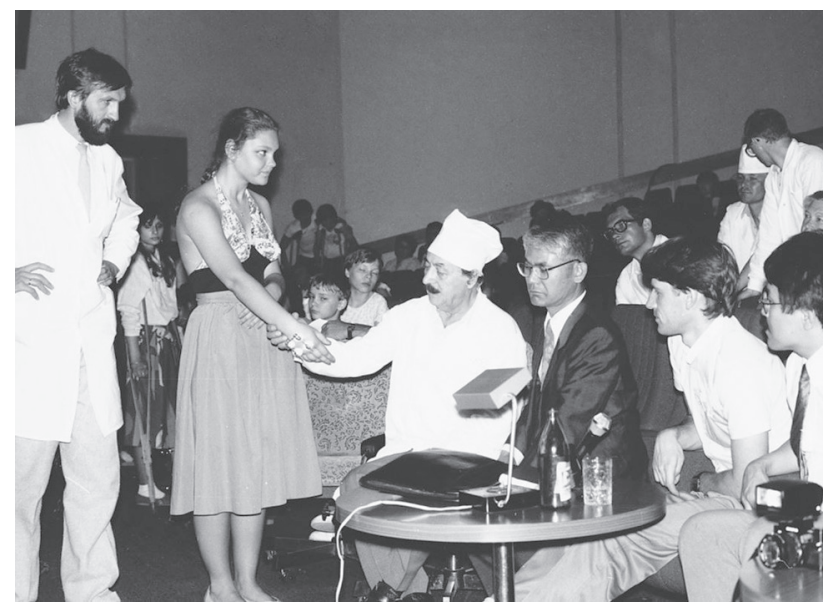

Fig. 12 Photos at the courses for foreign specialists, 1989. Academician G.A. Ilizarov, researcher A.P. Kirienko. Professor M. Kurokawa (Japan) is next to Professor G.A. Ilizarov

Special designs of the apparatus were invented for treatment of syndactyly. In 1989 the patent "Method for the treatment of syndactyly" was registered by Ilizarov GA: AC 1669436 (USSR) No 4683667/14 [23]. The author suggested to insert wires with olives through the phalanges of the fingers in the frontal plane with traction in opposite sides of each segment independently of each other in order to create a stock of soft tissues in the interdigital spaces in syndactyly (Fig. 13).

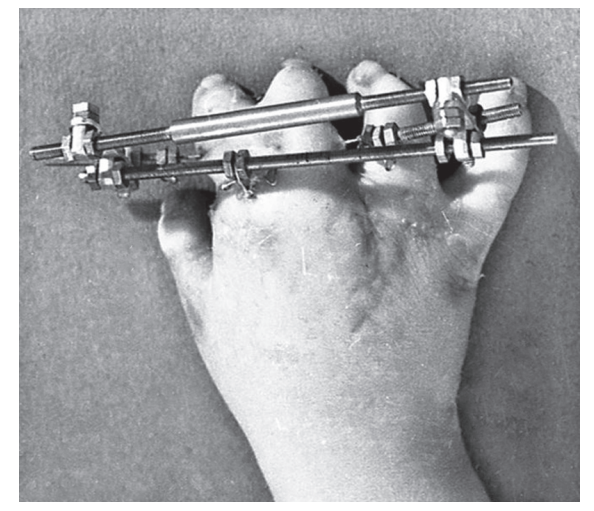

Fig. 13 Photo of patient D.'s hand (1981). Creation of soft tissues in the second interdigital space is shown under conditions of fixation with the Ilizarov apparatus

In 1991, fixation of wires on a common bar on each side of the ray was implemented with the rods on hinged connections between the bars (Author's Certificate 1669436 USSR) [23]. Since 1998, cantilever wires with twists have been fixed on rods that significantly reduce the weight and dimensions of the apparatus (certificate of the Russian Federation for useful models No. 7597) [24].

Patients with hand injuries were also admitted to the Ilizarov Center for treatment. Moreover, it cannot be said that this process was continuous. According to department reports, it was first from 1968 to 1970 . Between 1970 and 1978, the hand trauma was operated on only in the case when the 
patient had a concomitant injury and the parts of the standard Ilizarov apparatus were used. With the use of the Ilizarov mini-fixator (Inventor's Certificate No. 1715333 RF), new possibilities have opened up in hand surgery. The universal set of parts enables to assemble an optimal design that meets the conditions of reduction, stable fixation and functional treatment of various fractures. Patients with fractures of the bones of the hand began to be admitted to trauma departments, where they were assisted by surgeons, among them were Sysenko Yu.M., Novichkov S.I., Shved S.I., Glukhov D.V. and others. It is noteworthy to state that at that time, patients were regularly examined by Academician G.A. Ilizarov, and new inventions were born at such examinations (Fig. 14).

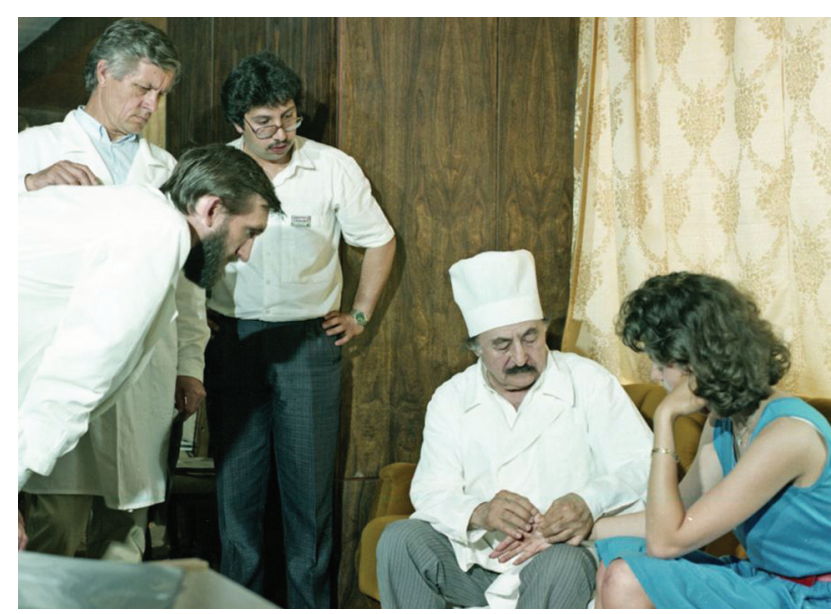

Fig. 14 Academician G.A. Ilizarov, Shevtsov V.I. and A.P. Kirienko discuss the patient's treatment plan (1989)

In total, G.A. Ilizarov presented at least 12 inventions on the osteosynthesis of short bones, two of them with co-authors. A patent was obtained for the use of a mini-fixator for lower jaw osteosynthesis, but this initiative was not widely used. We hope that there are active maxillofacial surgeons who could appreciate the positive characteristics of this device (Fig. 15) [25].

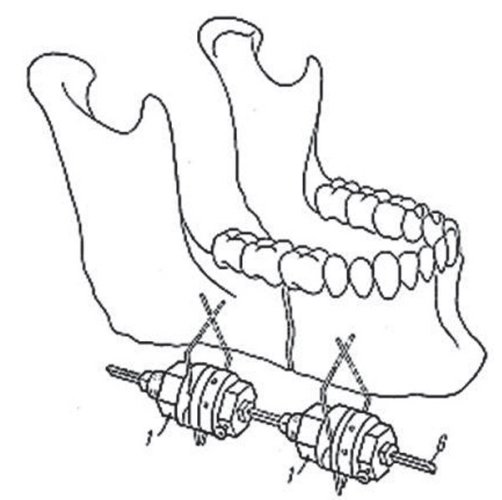

Fig. 15 Diagram of osteosynthesis for lower jaw fracture using the Ilizarov mini-fixator

Due to a large flow of patients and the specificity of the pathology of the hand and foot, the General Director of the Russian Ilizarov Research Center prof.
V.I. Shevtsov ordered to divide the department of hand and foot pathology into two separate structures in 2004, orthopedic department No. 2 (department for foot pathology) and orthopedic department No. 8 (department of hand pathology). They were headed, respectively, by candidates of medical sciences G.P. Ivanov and N.G. Shikhaleva.

Since that time, patients not only with orthopedic pathology, but also with acute hand injuries were referred to the new hand department. The monolocal arrangement of the mini-fixator nodes allowed simultaneous interventions on the palmar side of the hand. This design has been still widely used in various operations on short bones.

The referral of patients with open injuries of the hand and forearm promoted a widespread introduction of microsurgical technologies into practice, which began to be used to restore blood vessels and nerves with a diameter of less than 1-2 mm. For such injuries, hyperbaric oxygenation sessions were also applied. These procedures were especially widely used for crushed and fragmented injuries of the hand with impaired blood circulation in the tissues. In such situations, hyperbaric procedures were prescribed twice a day. This contributed to the saturation of damaged tissues with oxygen, relieving vasospasm, which made it possible to preserve damaged segments or reduce the volume of necrosis.

The accumulated experience of working with microstructures enables to start performing orthopedic operations to move tissue complexes with an axial type of blood supply (transposition and transplantation). Moreover, these reconstructions were often combined with the use of Ilizarov transosseous osteosynthesis.

Further development of the technology of reconstructive and restorative treatment promoted the inflow of patients with various pathologies of not only the hand, but also of other segments to be hospitalized in the hand department. A large group consisted of patients with rough scars after thermal and mechanical injuries. Also, the department began to admit patients with wound defects of various locations and sizes, including extensive ones, i.e. more than $1-2 \%$ of the area of the human body. By order of the director of the Center, A.V. Gubin on 01.08.2017, the Clinic for Reconstructive Plastic Surgery and Hand Surgery was organized, which consists of two departments (traumatology and orthopedic departments No. 13 and No. 14). N.G. Shikhaleva was appointed head of the clinic. The staff of doctors of the new unit is represented not only by orthopedic surgeons, but also by burn surgeons, plastic surgeons, and a neurosurgeon. It allows us to solve the most diverse and complex clinical and scientific problems. The hand surgery service at 
the Center is now carried out by a team of doctors: D.E. Tyagunov (head of the department), I.V. Chirkova,
A.V. Shamara, D.A. Shabalin, N.G. Shikhaleva, as well as residents and graduate students.

\section{RESULTS}

Summing up the above, it can be stated that the period of development, testing and active use of the Ilizarov mini-fixator represents several time intervals.

1. The period of comprehending the need for the invention of an external fixation device for short bones (1970s).

2. The period of appearance of the first models of the external fixation apparatus for short bones (19801983).

3. The period of the invention of the current design (1984).

4. The period of widespread introduction of the Ilizarov mini-fixator (1984-2003).

5 . The period of combined use with other types of surgical interventions (microsurgery, hand joint arthroplasty, prosthetics of tendons, various types of plasty of integumentary tissues) (from 2004 to the present).

During the existence of the Ilizarov Center, within the framework of the direction of "hand surgery", one doctoral dissertation was defended (N.G. Shikhaleva) [26], $7 \mathrm{PhD}$ theses: M.G. Znamenskaya [27], T.E. Kozmina [28], M.Yu. Danilkin [29],D.V. Glukhov[30],D.A. Shabalin [31], K.N. Onipko [32], D.S. Mokhovikov [33]. Books $[34,35]$, parts of monographs $[36,37]$, textbooks and manuals on the technologies $[38,39]$, etc. were prepared. Currently, the scientific work has not stopped and scientific directions continue to develop, including the study of Dupuytren's contracture, congenital anomalies in the development of the hand, soft tissue defects in the hand and forearm.

\section{CONCLUSIONS}

As can be seen from the above, the range of scientific interests of Academician G.A. Ilizarov also included one of the most difficult sections of traumatology and orthopedics, hand surgery. The presented inventions on transosseous osteosynthesis of the hand involve options for correcting various pathologies of this segment. Some of the inventions have been still used, others have only historical significance. The experience accumulated by G.A. Ilizarov and his disciples is invaluable because it was the basis for further developments in science and practical medicine.

In conclusion, it is necessary to note the great work of the team of scientists who made a valuable contribution to the development of hand surgery at our Center: I.A. Kataev, V.I. Shevtsov, A.P. Kirienko, G.R. Ismailov, Yu.M. Sysenko, S.I. Shved, M.G. Znamenskaya, D.V. Glukhov, T.E. Kozmina, M.Yu. Danilkin, N.A. Schudlo, and some others.

This work does not claim to be absolute truth in covering the development of the Ilizarov mini-fixator and hand surgery at the Center. We invite the readers to continue this topic in their publications.

The authors are grateful to the Head of the Patent Department A.P. Volosnikov, head of the film and photo laboratory R.A. Alekseev, employee of the film and photo laboratory Z.A. Kudyasheva.

\section{Funding information and conflicts of interest}

The authors of this work declare that there are no obvious or potential conflicts of interest associated with the publication of this manuscript.

The study was not sponsored.

\section{REFERENCES}

1. Newmeyer W.L. ${ }^{\text {rd. }}$ Sterling Bunnell, MD: The founding father. J. Hand Surg. Am., 2003, vol. 28, no. 1, pp. 161-164. DOI: 10.1053/jhsu.2003.50019.

2. Dudnikov A.V., Baitinger V.F. Istoriia khirurgii kisti v Rossii [History of the hand surgery in Russia]. Voprosy Rekonstruktivnoi $i$ Plasticheskoi Khirurgii, 2016, no. 4, pp. 64-75. (in Russian) DOI: 10.17223/1814147/59/09.

3. Nelzina Z.F. Neotlozhnaia khirurgiia otkrytykh povrezhdenii kisti i paltsev [Emergency surgery of open injuries of the hand and fingers]. M., Meditsina, 1980, 240 p. (in Russian)

4. Gubin A.V., Borzunov D.Iu., Marchenkova L.O., Smirnova I.L. Nauchnoe nasledie akademika G.A. Ilizarova: Vzgliad iz proshlogo v budushchee (Chast II) (95-letiiu so dnia rozhdeniia akademika G.A. Ilizarova, 65-letiiu metoda chreskostnogo osteosinteza po Ilizarovu posviashchaetsia [Academician G.A. Ilizarov's scientific heritage: a look into the future from the past (part II) (devoted to $95^{\text {th }}$ anniversary of Academician G.A. Ilizarov, $65^{\text {th }}$ anniversary of the transosseous osteosynthesis method according to Ilizarov)]. Genij Ortopedii, 2016, no. 3, pp. 6-13. (in Russian)

5. Zavarukhin V.I., Goliana S.I., Govorov A.V. Istoriia metoda distraktsionnogo osteosinteza v khirurgii kisti, ego razvitie i sovremennoe sostoianie [History of distraction osteosynthesis method in the hand surgery, its development and current state]. Ortopediia, Travmatologiia $i$ Vosstanovitelnaia Khirurgiia Detskogo Vozrasta, 2013, vol. 1, no. 1, pp. 72-76. (in Russian)

6. Shikhaleva N.G., Shchudlo N.A., Danilkin M.Iu., Shabalin D.A., Mokhovikov D.S., Tiagunov D.E., Chirkova I.V. Rol chreskostnogo osteosinteza po G.A. Ilizarovu v khirurgii kisti [The role of the transosseous osteosynthesis according to G.A. Ilizarov in the hand surgery]. Genij Ortopedii, 2011, no. 2, pp. 38-43. (in Russian)

7. Fominykh A.A., Goriachev A.N. Primenenie apparatov naruzhnoi fiksatsii v sovremennoi khirurgii kisti [Application of external fixation in modern hand surgery]. Genij Ortopedii, 2000, no. 4, pp. 60-65. (in Russian)

8. Vodianov N.M. Metod distraktsii v khirurgii kisti [Distraction method in the hand surgery]. Sb. nauch. trudov Leningr. NIITO "Tiazhelye Travmy Konechnostei" [Proceedings of the Leningrad Scientific Research Institute of Traumatology and Orthopaedics "Severe Injuries of Limbs"]. L., 1976, pp. 32-67. (in Russian) 
9. Volkov M.V., Oganesian O.V. Vosstanovlenie formy i funktsii sustavov i kostei (apparatami avtorov) [Restoration of the shape and function of joints and bones (with the authors' devices)]. M., Meditsina, 1986, 256 p. (in Russian)

10. Apparat dlia lecheniia perelomov kostei kisti [The device for treating fractures of the hand bones]. Author's license no. 1189444 SSSR, A61 B17/60, 1984. (in Russian)

11. Apparat dlia lecheniia perelomov kostei kisti [The device for treating fractures of the hand bones]. Author's license no. 1789206 SSSR, A61 B17/58, 1990. (in Russian)

12. Spitsederzhatel [The wire-fixator]. Author's license no. 923535 SSSR, A61 B 17/18, 1980. (in Russian)

13. Ustroistvo dlia fiksatsii i razrabotki sustavov paltsev [The device for fixation and development of fingers' joints]. Author's license no. 973115 SSSR, A61 B 17/18, 1981. (in Russian)

14. Kompressionno-distraktsionnyi apparat [The compression-distraction apparatus]. Author's license no. 1715333 SSSR, A61 B 17/58, 1986. (in Russian) 15. Distraktsionnyi apparat [The distraction apparatus]. Author's license no. 1237189 SSSR, A61 B 17/58, 1984. (in Russian)

16. Kompressionno-distraktsionnyi apparat [The compression-distraction apparatus]. Author's license no. 1708320 SSSR, A61 B 17/58, 1987. (in Russian)

17. Sposob lecheniia sgibatelnykh kontraktur kisti [The way of treating flexion contractures of the hand]. Author's license no. 1442197 SSSR, A61 B 17/56, 1986. (in Russian)

18. Kompressionno-distraktsionnyi apparat [The compression-distraction apparatus]. Author's license no. 1708319 SSSR, A61 B $17 / 60,1987$. (in Russian)

19. Kompressionno-distraktsionnyi apparat [The compression-distraction apparatus]. Author's license no. 1708322 SSSR, A61 B 17/60, 1987. (in Russian)

20. Ilizarov G.A. Traction apparatus for osteosynthesis of short tubular bones. Pat. SU 8800152 WO. IPC A61B 17/64 2006.01; A61B 17/66 2006.01. CPC A61B 17/6425; A61B 17/6441; A61B 17/66, 1988.

21. Ilizarov G.A. Distraction apparatus for plastic reconstruction of hand. Pat. SU 8800140WO. SU SU802969649A patent/SU959768A1, 1988.

22. Sposob lecheniia gipoplazii kisti [The way of treating the hand hypoplasia]. Author's license no. 1683714 SSSR, A61 B 17/56, 1986. (in Russian)

23. Sposob lecheniia sindaktilii [The way of syndactyly treatment]. Author's license no. 1669436 SSSR, 1989. (in Russian)

24. Shevtsov V.I., Ismailov G.R., Danilkin M.Iu. Ustroistvo dlia lecheniia patologii paltsev [The device for treatment of finger pathology]. Pat. RF No 7597 / No 97115848/20, 1997. (in Russian)

25. Ilizarov G.A. Compression-distraction apparatus for osteosynthesis. Pat. SU 8800131 WO. US-4978348-A, 1988.

26. Shikhaleva N.G. Lechenie bolnykh s otkrytoi travmoi kisti i miagkikh tkanei distalnoi treti predplechia s ispolzovaniem metoda chreskostnogo osteosinteza. Diss. dokt. med. nauk [Treatment of patients with open injury of the hand and soft tissues of the forearm distal third using transosseous osteosynthesis method. Dr. med. sci. diss.]. Kurgan, 2013, 305 p. (in Russian)

27. Znamenskaia M.G. Lechenie po Ilizarovu vrozhdennoi sindaktilii kisti u detei. Diss. kand. med. nauk [Treatment of the hand congenital syndactyly in children according to Ilizarov. Cand. med. sci. diss.]. Kurgan, 2001, 133 p. (in Russian)

28. Kozmina T.E. Lechenie bolnykh s gipoplaziei kisti s primeneniem chreskostnogo osteosinteza po Ilizarovu. Diss. kand. med. nauk [Treatment of patients with the hand hypoplasia using the transosseous osteosynthesis according to Ilizarov. Cand. med. sci. diss.]. Kurgan, 1998, 150 p. (in Russian)

29. Danilkin M.Iu. Operativnoe udlinenie posttravmaticheskikh kultei paltsev kisti i piastnykh kostei. Diss. kand. med. nauk [Surgical lengthening of posttraumatic stumps of the hand fingers and metacarpal bones. Cand. med. sci. diss.]. Kurgan, 2002, 128 p. (in Russian)

30. Glukhov D.V. Lechenie bolnykh s zakrytymi perelomami trubchatykh kostei kisti metodom chreskostnogo osteosinteza. Diss. kand. med. nauk [Treatment of patients with closed fractures of the hand tubular bones by transosseous osteosynthesis method. Cand. med. sci. diss.]. Kurgan, 2004, 146 p. (in Russian)

31. Shabalin D.A. Metod chreskostnogo osteosinteza v formirovanii pervogo paltsa kisti v sluchaiakh ego vrozhdennogo otsutstviia i travmaticheskikh povrezhdenii. Diss. kand. med. nauk [Transosseous osteosynthesis method in forming the hand first finger in cases of its absence and traumatic injuries. Cand. med. sci. diss.]. Kurgan, 2009, 143 p. (in Russian)

32. Onipko K.N. Operativnaia korrektsiia apparatom Ilizarova posttravmaticheskikh deformatsii kostei kisti. Diss. kand. med. nauk [Surgical correction of posttraumatic deformities of the hand bones. Cand. med. sci. diss.]. Kurgan, 2009, 130 p. (in Russian)

33. Mokhovikov D.S. Zameshchenie postrezektsionnykh defektov trubchatykh kostei kisti s primeneniem metoda chreskostnogo osteosinteza. Diss. kand. med. nauk [Filling post-resection defects of the hand tubular bones using transosseous osteosynthesis method. Cand. med. sci. diss.]. Kurgan, 2013, 159 p. (in Russian)

34. Popkov A.V., Varganov E.V., Danilkin Iu.M. Lechenie bolnykh s ognestrelnymi raneniiami kisti i ikh posledstviiami. Rukovodstvo dlia vrachei [Treatment of patients with the hand gunshot wounds and their consequences. Manual for physicians]. Cheliabinsk, Fotokhudozhnik, 2011, 255 p. (in Russian)

35. Shabalin D.A., Dolganova T.I., Gorbach E.N. Metod chreskostnogo osteosinteza v formirovanii pervogo lucha kisti: fiziologicheskie $i$ morfologicheskie izmeneniia $v$ tkaniakh udliniaemogo segmenta: monografiia [Transosseous osteosynthesis method in formation of the hand first ray: physiological and morphological changes in the tissues of the segment lengthened. Monograph]. Saarbrücken (Deutschland), LAP LAMBERT Academic Publishing, 2012, 144 p. (in Russian)

36. Shikhaleva N.G., Shevtsov V.I., Danilkin M.Iu. Osnovy chreskostnogo osteosinteza v khirurgii kisti [Basics of transosseous osteosynthesis in the hand surgery]. In: Solomin L.N., editor. Osnovy chreskostnogo osteosinteza [Basics of transosseous osteosynthesis]. M., Binom, 2015, vol. 3, pp. 1080-1103. (in Russian)

37. Shevtsov V.I., Shikhaleva N.G. Udlinenie korotkikh trubchatykh kostei kisti i stopy [Lengthening of the hand and foot short tubular bones]. Shevtsov V.I. Chreskostnyi osteosintez po Ilizarovu: teoriia i praktika. Tom 3. Klinicheskie aspekty [Transosseous osteosynthesis according to Ilizarov: theory and practice. Vol. 3. Clinical aspects]. Saarbrücken (Deutschland), Palmarium Academic Publishing, 2018, pp. 227-302. (in Russian)

38. Shevtsov V.I., Danilkin M.Iu., Shikhaleva N.G., Shabalin D.A., Neretin A.S., Tiagunov D.E., compilers. Osteosintez zakrytykh neoskolchatykh perelomov korotkikh trubchatykh kostei kisti : med. tekhnologiia [Osteosynthesis of closed non-comminuted fractures of the hand short tubular bones. Technique manual]. Kurgan, 2007, 31 p. (in Russian)

39. Korostelev M.Iu., Shikhaleva N.G. Primenenie autodermoplastiki polnosloinymi transplantatami v tramatologii i ortopedii [Application of autodermoplasty using full-thickness grafts in traumatology and orthopedics]. In: Bogdanov S.B., Gilevich I.V., Karakulev A.V., Blazhenko A.N., Kurinnyi S.N., Mukhanov M.L., Korostelev M.Iu., Shikhaleva N.G., Fistal E.Ia., Sotnichenko A.S. Plastika polnosloinymi kozhnymi autotransplantatami: ucheb. posobie dlia vrachei [Plastics with full-thickness skin autografts. Study guide for physicians]. Krasnodar, 2020, Ch. 3, pp. 258-310. (in Russian)

Received: 19.01.2021

Information about the authors:

1. Vladimir I. Shevtsov, M.D., Ph.D., Professor, Honored Scientist of the Russian Federation, Corresponding Member of the Russian Academy of Sciences, Honorary Professor Ilizarov Center,

Email: shevtcov3838@mail.ru

2. Alexander P. Kirienko, M.D.,

Humanitas Clinical and Research Center IRCCS, Milan, Italy,

Email:alexander@kirienko.com

3. Natalia G. Shikhaleva, M.D., Ph.D.,

Ilizarov National Medical Research Centre for Traumatology and Orthopedics, Kurgan, Russian Federation,

Email: nshihaleva@mail.ru

4. Konstantin I. Novikov, M.D, Ph.D.,

Ilizarov National Medical Research Centre for Traumatology and Orthopedics, Kurgan, Russian Federation, Email: kinovikov@mail.ru 